\title{
ILMENITE AND SILICATE MEGACRYSTS FROM HAMILTON BRANCH: TRACE ELEMENT GEOCHEMISTRY AND FRACTIONAL CRYSTALLIZATION.
}

\author{
W.L. Griffin ${ }^{(1)}$; C.G. Ryan ${ }^{(1)}$ and D.J. Schulze ${ }^{2}$.
}

(1) CSIRO Div. of Exploration Geoscience, Box 136, North Ryde, NSW 2113, Australia; (2) Dept. of Geology,

Univ. of Toronto, Erindale College, Mississuagua, Ontario L5L1C6, Canada.

Introduction: The Hamilton Branch kimberlite in eastern Kentucky contains a welldeveloped suite of ilmenite and silicate (cpx+opx+gnt) megacrysts. The ilmenites range in $\mathrm{MgO}$ from $15 \%$ to $9 \%$ and in $\mathrm{Cr} 2 \mathrm{O} 3$ from $5 \%$ to $0.2 \%$, describing a rough parabola in a $\mathrm{Cr}-\mathrm{Mg}$ plot (Fig. 1;Schulze, 1984). High-Cr, high-Mg ilmenites occur as inclusions in silicates, and lower- $\mathrm{Cr}$, high-Mg ones in intergrowths with clinopyroxene; small silicate inclusions occur in low-Cr ilmenites with $12-14 \% \mathrm{MgO}$. No silicates are known to be associated with the ilmenites containing $<12 \% \mathrm{MgO}$. This trend has been interpreted as the result of fractional crystallization; a continuous increase in $\mathrm{Ca} /(\mathrm{Ca}+\mathrm{Mg})$ in clinopyroxene with decreasing $\mathrm{Cr}$ in silicates and ilmenite suggests that silicates and ilmenite crystallized together over a T range from ca. 1450$1200^{\circ} \mathrm{C}$. This study presents trace-element data, obtained by proton microprobe, on the ilmenites and associated clinopyroxene, and provides further information on the processes of fractional crystallization that have produced the ilmenite megacrysts.

Data: Schulze (1984) showed that $\mathrm{Cr}$ in cpx decreases as $\mathrm{Ca} /(\mathrm{Ca}+\mathrm{Mg})$ increases, i.e. with declining $\mathrm{T}$. Our data show that $\mathrm{Ni}$ in cpx also decreases, and $\mathrm{Zr}$ increases, as $\mathrm{Cr}$ and $\mathrm{Mg}$ decrease; these trends are consistent with the fractional crystallization model. Sr in cpx decreases slightly, from $180-140 \mathrm{ppm}$, as Ni drops from $350-110 \mathrm{ppm}$, then drops to $80 \mathrm{ppm}$ at $60 \mathrm{ppm} \mathrm{Ni}$. This trend suggests that clinopyroxene was a major fractionating phase, and is consistent with its abundance in the megacryst assemblage.

$\mathrm{Nb}$ in ilmenite ranges from $400-2600 \mathrm{ppm}$, and is positively correlated with $\mathrm{Zr}$ (250-900 ppm) (Fig. 2). $\mathrm{Nb}$ shows a strong negative correlation with $\mathrm{Mg}$ in ilmenite (Fig. 3), while the $\mathrm{Mg}$ content of the ilmenites is positively correlated with $\mathrm{Mg}$ in coexisting silicates. $\mathrm{Nb}$ and $\mathrm{Zr}$ appear to have behaved as incompatible elements during the entire crystallization process, and the $\mathrm{Nb}$ content of the ilmenites is therefore taken as an index of fractionation.

Most of the increase in the $\mathrm{Nb}$ content of ilmenite takes place after $\mathrm{MgO}$ has declined below $12 \%$, i.e. after the point where coexisting silicates have not been recognized. The $\mathrm{Cr}$ and $\mathrm{Ni}$ contents of ilmenites decrease as $\mathrm{Nb}$ rises; Cr drops to its minimum value at a lower $\mathrm{Nb}$ content than does $\mathrm{Ni}$ (Figs. 4,5). The smooth covariation of $\mathrm{Mg}$ and $\mathrm{Ni}$ against $\mathrm{Nb}$ is interupted by a major spike at ca. $1000 \mathrm{ppm} \mathrm{Nb}$; Ni rises from 200-950 ppm, and $\mathrm{MgO}$ from $12.5-15 \%$, at essentially constant $\mathrm{Nb}$ and $\mathrm{Zr}$. Another possible spike is represented by 2 points near 2000 ppm Nb.

A12O3 in ilmenite decreases steadily ( from $>1 \%$ to $0.25 \%$ ) as $\mathrm{Nb}$ increases. Ga contents of ilmenites show a weak and irregular increase from ca. $12 \mathrm{ppm}$ to ca. $20 \mathrm{ppm}$ with increasing $\mathrm{Nb}$. Zn contents also rise, from ca. $100-120 \mathrm{ppm}$, following the end of silicate crystallization, then fall slowly again. $\mathrm{Nb} / \mathrm{Ta}$ varies irregularly at first, then rises from 6 to 8 as $\mathrm{Nb}$ increases from $1000-2600 \mathrm{ppm}$.

Discussion: The smooth covariance of $\mathrm{Ni}, \mathrm{Zr}$ etc. against $\mathrm{Nb}$ is typical of ilmenite megacryst suites from kimberlites and some lamproites, worldwide (Moore et al., 1991; Griffin and Ryan, unpubl.). These smooth variations are generally consistent with the fractional crystallization of a single batch of magma. At Hamilton Branch, most of the rise in the $\mathrm{Nb}$ and $\mathrm{Zr}$ contents of ilmenite takes place after mafic silicates apparently stopped crystallizing; this corresponds to the late stages of crystallization, at $\mathrm{T}<1200^{\circ} \mathrm{C}$. Simple calcilations, treating $\mathrm{Nb}$ and $\mathrm{Zr}$ as perfectly incompatible elements, show that $>60 \%$ of the liquid crystallized between the beginning of ilmenite precipitation and the end of cpx crystallization. Half of the remainder crystallized to produce the lowest- $\mathrm{Mg}$, highest- $\mathrm{Nb}$ ilmenites. Since $\mathrm{Nb}$ and $\mathrm{Zr}$ were obviously not completely incompatible, these are minimum estimates of the degree of crystallization, and any pre-ilmenite crystallization of mafic silicates would raise these estimates. The rise in $\mathrm{Nb} / \mathrm{Ta}$ of the ilmenites at high $\mathrm{Nb}$ is further evidence of extreme fractional crystallization.

The major spike in the $\mathrm{Ni}-\mathrm{Nb}$ and $\mathrm{Mg}-\mathrm{Nb}$ curves (Figs. 2-4) is interpreted as the result 
of mixing between the main batch of magma and a similar, less-fractionated magma. This would have the most severe effects on the strongly depleted, compatible elements, but less on $\mathrm{Nb}$ and $\mathrm{Zr}$. Similar magma-mixing episodes earlier in the sequence may have contributed to the scatter in the high-Mg limb of the Mg-Cr plot (Fig. 1); these would be difficult to recognize without the enrichment of $\mathrm{Nb}$ and $\mathrm{Zr}$ as benchmarks.

Schulze (1984) argued that other phases (olivine, phlogopite and/or carbonate) must have crystallized together with ilmenite in the late stages of fractionation, to prevent the magma from being enriched in $\mathrm{Mg}$. However, the relatively gradual drop in $\mathrm{Ni}$, and the fact that the $\mathrm{Ni}$ content of ilmenite does not drop below 100 ppm, suggest that olivine was not a coprecipitating phase. However, the fact that $\mathrm{Ni}$ appears to remain constant as $\mathrm{Nb}$ increases from 1000 to $>2000$ ppm argues for the crystallization of a Ni-bearing phase, perhaps sulfide. $\mathrm{Cr}$ is incompatible at this stage, rising from 0.2 to $0.4 \%$ (Fig. 1). The slow drop in Al during the fractionation may reflect the precipitation of phlogopite, but the rise in Ga during the late fractionation would appear to contradict this. The ilmenites from the Twin Knobs lamproite (Griffin et al, 1991) are quite similar to those from Hamilton Branch, but show a rise in Ni and $\mathrm{Cr}$ equivalent to the rise in $\mathrm{Nb}$ late in the fractionation, consistent with the absence of any mafic silicates in the cumulate assemblage.

The high $\mathrm{Nb}$ and $\mathrm{Zr}$ contents of the ilmenites, compared to the $\mathrm{Nb}$ and $\mathrm{Zr}$ contents of known magmatic rocks, suggest that ilmenite/magma $K_{D}$ values for these elements are $>1$. The apparently continuous rise in $\mathrm{Nb}$ and $\mathrm{Zr}$ during fractionation, despite the high $\mathrm{Nb}$ and $\mathrm{Zr}$ contents of ilmenite, therefore implies that ilmenite was never more than a minor phase in the cumulate assemblage. If olivine and phlogopite are ruled out as late cumulate phases, then carbonate may be required to buffer the Mg content of the liquid, as suggested by Schulze (1984).

The low-Mg, moderate-Cr ilmenites that define the low-Mg arm of the "parabola" in Fig. 1 may not be related to the main ilmenite assemblage. Both analyzed grains lie off the main $\mathrm{Nb}-\mathrm{Ni}$ curve, and one has lower $\mathrm{Zr}$ than the main trend. While they appear on Fig. 1 to represent the latest stages of fractionation, they do not have the highest $\mathrm{Nb}$ contents. There is therefore no clear evidence that they represent a continuation of the main fractionation trend. However, their high $\mathrm{Nb}$ and $\mathrm{Zr}$ contents show that they are late-stage ilmenites, and they may be from a related but separate batch of cumulates, sampled by the ascending kimberlite.

Griffin, W.L., O'Reilly, S.Y., Ryan, C.G. and Waldman, M.A., 1991 (this vol).

Moore, R.O., Griffin, W.L., Gurney, J.J., Ryan, C.G., Cousens, D.R., Sie, S.H. and Suter, G.F., 1991. Contrib. Mineral. Petrol., in press.

Schulze, D.J., 1984. in Kornprobst, J. (ed.) Kimberlites II: the Mantle and Crust-Mantle Relationships. Elsevier, Amsterdam. pp. 97-108. 


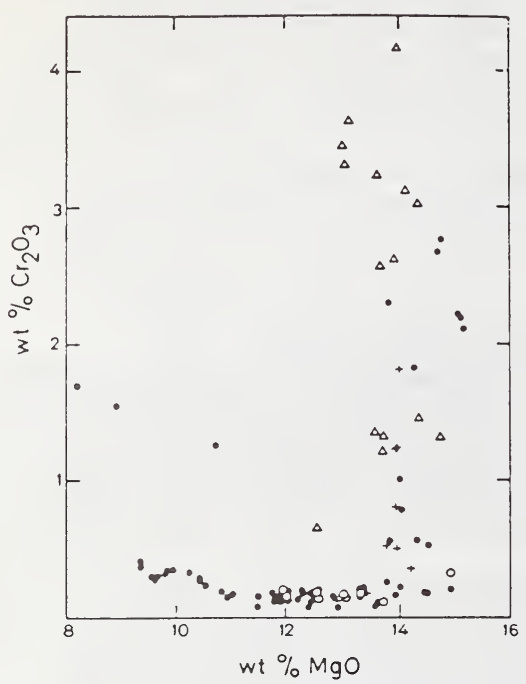

Fig. 1. $\mathrm{Mg}-\mathrm{Cr}$ in Hamilton Branch ilmenites. Triangles: tiny ilmenites in silicate megacrysts; crosses, cpx-ilm intergrowths; open circles, ilmenites with silicate inclusions; dots, monomineralic ilmenites.
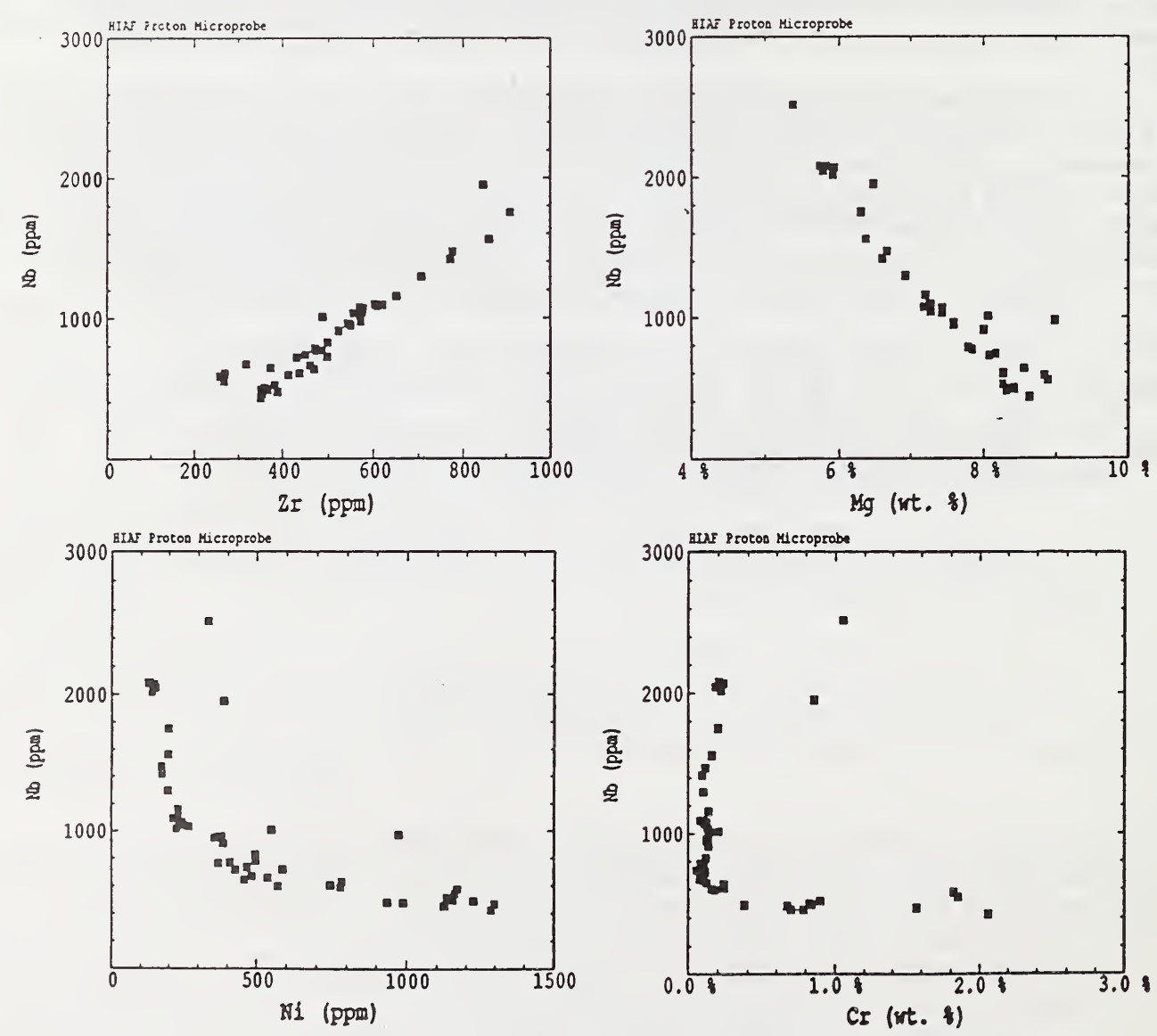

Fig. 2. $\mathrm{Nb}-\mathrm{Zr}$ relations in ilmenites Fig. 3. Nb-MgO relations in ilmenites Fig. 4. $\mathrm{Nb}-\mathrm{Cr}$ relations in ilmenites Fig. 5. Nb-Ni relations in ilmenites 